\title{
Integrative space of a pedagogical university as a qualitative resource for successful self- actualization of future teachers in a city context
}

\author{
Aleksandr Makhinin ${ }^{1 *}$, Tamara Kozlova ${ }^{2}$, Irina Nesterova $^{2}$, and Liliya Shamanina ${ }^{3}$ \\ ${ }^{1}$ Voronezh State Pedagogical University, Department of General Pedagogy, Voronezh, Russia \\ ${ }^{2}$ Voronezh State Pedagogical University, Department of Social Pedagogy, Voronezh, Russia \\ ${ }^{3}$ Voronezh State Pedagogical University, Department of Technical and Natural Science Disciplines, \\ Voronezh, Russia
}

\begin{abstract}
In the context of the unstable development of contemporary civilization, attempts to consolidate efforts among the pedagogical community to ensure the proper quality of education in the $21^{\text {st }}$ century are becoming more and more relevant. It seems that the solution to such an urgent problem is feasible by developing an additive integrated model of pedagogical management based on the implementation of the integrative educational space of a pedagogical university (hereinafter - IESPU). According to the authors, the emergence and constant reproduction of relationships between the administration and employees of educational organizations of higher education to achieve the strategic goals of the university should become the main goal of developing such a pedagogical university management model. The methodological basis for the development and implementation of an additively integrated model of pedagogical management is the integrative and spatial approaches that determine the feasibility of designing IESPU and allowing providing access to the formation of teachers' subjectivity in their own professional activities in the context of continuous personal and professional selfdevelopment. The authors consider it appropriate to offer a certain set of areas, essential in their opinion, for planning and developing an additive model of pedagogical management in the context of designing and implementing IESPU, taking into account its qualitative, spatial-temporal, socially-determined, and scientifically-grounded parameters, as well as the urban environment in which pedagogical universities are located.
\end{abstract}

Keywords: integrative educational space, quality, social responsibility, self-actualization.

\section{Introduction}

In the context of the contemporary socio-cultural situation, higher education is one of the conditions for effective adaptation and self-actualization in constantly changing, unpredictable conditions. In general, one should agree with expert assessments that it is

\footnotetext{
* Corresponding author: alex-makhinin@yandex.ru
} 
exactly "the system of higher pedagogical education that today is in urgent need of updating goals and objectives, requires the development of innovative approaches to achieving the effectiveness of teacher training based on integrity, openness, flexibility, variability, economic feasibility, which is relevant to the current agenda" [1]. According to the authors, the relevance of this problem is due to the contradiction between the "standardization and regulation of educational activities at higher education institution" [2] due to the presence of the social order system of education, the national normative documents, educational standards, and the need to create space for teachers' freedom of creativity, ensuring flexibility in approaches to educational content, testing and implementation of the latest results of scientific research of pedagogical science in the educational process. At that, teachers should master the totality of professional competencies, the attitude to continuous self-education and self-development by mastering effective tools and valid methods of "immersion in the variety of professional-forming environments, professional training systems with information and educational resources that should be integrated into a certain metasystem structure" [3], and, finally, they should be actualized in the professional community, feel the need for personal and professional growth as a significant subjective characteristic of their own pedagogical activity.

There are already some foreign scientific publications on these issues and practices of educational systems management [3-8], but they suffer from a lack of conceptual clarity and do not allow approaching to general theoretical generalizations and patterns. In the Russian practice of studying management problems in higher education, its content, structural, and technological components are considered in the research of A.K. Klyuev [9], M.N. Pevsner [10], D.V. Polyakov [1], V.M. Filippov [11], I.D. Frumin [12], and others. However, it should be emphasized that in the presented studies of pedagogical management issues, focused attention is paid mainly to only one criterion, namely, the quality of education, while other aspects are not almost touched upon. At that, there are practically no scientific and methodological publications describing these areas. All this together makes it difficult for educational organizations to "reach a new level of management development and move to the formation of integrated systems" [8]. Thus, attracting the attention of researchers to the issues of pedagogical management, the authors insist on the expediency and timeliness of developing an additive strategy of pedagogical management as a target setting due to the challenges of modern civilization, assuming that this will allow integrating a set of process and system approaches to education management and the leadership of the principal into a rational management complex, as well as unite the administration and teaching staff based on common strategic goals and effective concern for continuous personal advancement and professional development, self-development, and joint responsibility.

\section{Methods}

The research was theoretical. It was supplemented with scientific and methodological content that allowed using the conclusions for organizing the work of teaching staff of educational organizations. As a methodological basis for designing a system of additive pedagogical management that could solve these problems, the authors turned to integrative and spatial approaches that provided "the need to design an integrative educational space of a pedagogical university" [2]. 


\section{Results}

The results of theoretical and practical analysis convincingly show that to date, the management practice of Russian and foreign pedagogical universities has accumulated a lot of problems, which largely were caused by the accepted models of higher school management, "ensuring reproducibility and continuous improvement of the educational process" [11]. These problems complicate the training of a contemporary teacher in the situation of the current agenda for the development of integrated systems, creating communication and strategic unity of administration, teaching staff, students, other subjects and resources of professional-forming environments in the system of higher pedagogical education in the context of the current agenda and the growth of integration processes in education. In this context, it is also necessary to emphasize the special role of the urban environment, which should be considered as an open educational environment, and therefore, whose components and elements (such as the development level of infrastructure, education, culture, local self-government, etc.) are most closely connected with the existing university architecture in cities, and thus have impact on the professional training of specialists, in particular, future teachers. Such a relationship can be expressed in the fact that urban specifics affect the IESPU, the quality and adaptation components of the professional activity of future teachers in a highly competitive urban environment filled with numerous risks and opportunities.

To improve the quality of life of future teachers from the very beginning of their professional adaptation, as well as for retention in the profession, and professional and personal self-actualization, the authors believe it timely to discuss the development and implementation of the IESPU project, which is generally determined by the combination of general patterns of change and development of educational systems, which is known to pedagogical science, is a subject for pedagogical design and modeling, and at the same time, has real and potential (hidden) resources to ensure contemporary quality standards in the field of formation of professional competence of subjects in the system of pedagogical education. It should be emphasized that the authors consider IESPU as a living and selfdeveloping empirical-rational semantic reality, represented by a set of different types of professional-forming environments (clusters), the mass media, social partners of pedagogical universities, etc., aimed at achieving a common integrative synergetic effect in the quality training of teachers.

Studies allow identifying a set of systemic and qualitative characteristics of IESPU. According to the workgroup led by L.L. Redko, the first group should include "territorial integrity, openness, eventfulness, educational extension, hierarchy, in-touch capabilities, variable flexibility, the fullness with various resources, dynamism, structural coexistence of systems and their components that do not contradict each other, open-mindedness to life, multidimensionality and intensity of educational services that ensure the creation of diverse conditions for determining the personal development trajectory of subjects" [2]. To the second group, researchers refer "interaction of a general with an orientation towards unity (preservation of a single educational space); individual (taking into account the specifics of the region), and special (ways of building space), which ensures the dialectical nature of integration processes according to regional, socio-economic, geographical, cultural, demographic, and other conditions" [2].

It is fundamental for understanding that the IESPU can produce a variety of educational and upbringing events, the implementation and/or co-participation in which can lead to the actualization of the subject-based position (or at least activity) of IESPU participants, allowing them to be involved in situations of problematization, testing, multiple-choice, etc. in the context of professional behavior and self-development. Thus, this refers to the need to create an additive (from lat. "additio" - "addition") model of an integrated system of 
pedagogical management that can ensure the integration of the above-mentioned professional-forming environments (clusters), their system and quality characteristics, taking into account their resource provision, into a single complex based on the integration of procedural and system approaches to managing educational systems, and the responsible attitude of the pedagogical university administration, loyalty (in the sense of belonging to common values and meanings) of teaching teams by understanding the general social responsibility for the results of work and fulfilling the social order for the training of competent teaching staff.

\section{Discussion}

The following, most significant main development directions of an additive model of pedagogical management in the context of the implementation of IESPU are proposed for discussion:

- unity of composing professional-forming environments (clusters) of IESPU,

- integrating the composing professional-forming environments (clusters) into a holistic-semantic unity,

- providing communication and integrative synchronization of IESPU participants due to a coordinated assessment and understanding of the value-semantic, target, and technological components of IESPU implementation,

- avoiding coincidence in the organizational, content, target, and activity implementation of the IESPU,

- adaptability of IESPU participants to the contemporary requirements of the social order and state regulatory documents in the field of training of competent teachers,

- continuity and dynamism in the development of IESPU,

- ensuring the proper degree of integration (reflected in the centralized and formal plans of the IESPU) of the IESPU subjects.

Taking into account the above-considered transition to the additive model of pedagogical management in the context of the implementation of IESPU, the authors offer also some of the techniques and methods of the integration program of additive pedagogical management in basic structural areas of management, as such:

- Planning (centralized and formal plan, a detailed plan of IESPU and clear goals, prioritizing actions to achieve integration benefits, scheduling informal meetings, planning synergy, and failure scenarios).

- Monitoring the implementation of the IESPU (formal management of the IESPU, its regular assessment, strengthening support, and stability of the staff composition).

- Organizational aspects of IESPU management (the responsibility of the administration, participation of the Academic Council of the university and the staff, IESPU as the subject of scientific research at the university).

\section{Conclusion}

Thus, the understanding of the crisis nature of the contemporary pedagogical education development in the context of changing its paradigm causes a shift in the research focus toward more and more closely studying of issues related to the quality of teacher education and an effective model of pedagogical management as a condition for its implementation. The authors believe that currently there is a need for development and gradual transition (through the testing procedure) to an additive model of pedagogical management in higher education through the creation of IESPU, which should be considered as an integral, ordered, open, and developing system of professional-forming environments (clusters). 
These clusters are linked with each other by common qualitative, spatial-temporal, sociallydetermined and scientifically-grounded parameters and common determinants, which, in general, should contribute to the actualization of the integrating potential of additive pedagogical management, and ensure coordinated interaction of participants in higher education institution aimed at forming in the teaching staff of subjectivity in their own professional activities in the context of continuous personal and professional selfdevelopment and an urban environment filled with risks and opportunities.

\section{Acknowledgments}

The article was prepared with the financial support of the Russian Foundation for Humanities (RFH), project No. 18-013-00613 A(f) "Socio-pedagogical determinants of the formation of integrative properties of educational systems".

\section{References}

1. D.V. Polyakov et al., Integrated educational process management system at the university, in New educational technologies at the university: Fifth international scientific and methodological conference: collection of abstracts, 4-6 February 2008, Ekaterinburg, Russia (2008)

2. L.L. Redko, A.V. Shumakova, V.G. Veselova, Designing an integrative educational space of a pedagogical university (Stavropol state pedagogical institute, Stavropol, 2010)

3. C. Griese, H. Marburger, Bildungsmanagement (Walter de Gruyter, Oldenbourg, 2011)

4. F. Decker, Bildungsmanagement für eine neue Praxis [Education Management for a New Practice] (AOL-Verl, Lichtenau, 1995)

5. I. Diesner, Bildungsmanagement in Unternehmen: Konzeptualisierung einer Theorie auf der normativen und strategischen Ebene (Gabler, Wiesbaden, 2008)

6. M. Fullan, The Meaning of Educational Change (Ontario Institute for Studies in Education, Toronto, 1991)

7. S.G. Huber, Hand buch für Steuergruppen. Grund lagen für die Arbeit in zentralen Handlungsfeldern des Schulmanagements [Control group manual. Basics for working in central areas of activity in school management] (LinkLuchterhand, Köln, 2009)

8. U. Müller, Lernen am Unterschied. Bildungsprozesse gestalten - Innovationen vorantreiben, 99 (2007)

9. A.K. Klyuev, A.A. Yashin, A.P. Bagirova, Modern Competition, 3(1(73)), 6-16 (2019)

10. M.N. Pevzner, P.A. Petryakov, V.A. Stadnik, U. Algermissen, Diversity management in heterogeneous organizations. (FOP A.S. Gonta, Khmelnitsky, 2016)

11. V.M. Filippov et al., Management in higher education: experience, trends, prospects (Logos, Moscow, 2005)

12. Ya.I. Kuzminov, I.D. Frumin, A.B. Zakharov, Educational Issues, 3, 5-54 (2011)

13. S.A. Mikheeva, Upravleniye obrazovaniyem: teoriya i praktika, 2(30), 11-24 (2018)

14. A.G. Shirin, M.N. Pevzner, O. Graumann, Higher education in Russia, 6, 123-132 (2009)

15. National Quality Assurance, (NQA Global Sertification Body, n.d.). Accessed on: December 20, 2020. [Online]. Available: www.nqa.com 
16. S. Polbitsyn, A. Kliuev, A. Iashin, "Can entrepreneurs drive the Russian economy into the future?" in Proceedings of the 14th European Conference on Innovation and Entrepreneurship, ECIE 2019. 19-20 September 2019, Kalamata, Greece, (2019)

17. V. A. Sitarov, Issues of new economy, 3(31), 101-109 (2014) 